\title{
A Comparison of Heating Protocols for the Cyclization of Melanotan II on the Prelude ${ }^{\circledR} \mathbf{X}$
}

\author{
Daniel Martinez, James P. Cain, Elizabeth Restituyo-Rosario, \\ Katya Karankevich, Peter Bergwall, and Nathaniel Cosper
}

Protein Technologies, Inc., Tucson, AZ, 85714, USA, Website: www.ptipep.com, Email: info@ptipep.com

\section{Introduction}

Cyclic peptides typically offer enhanced stability as well as increased potency and selectivity for biological targets compared to their linear counterparts. A number of methods for on-resin cyclization of peptides have been described, allowing for convenient automation; however, depending on the sequence, cyclization of synthetic peptides may be a challenging and time-consuming process.

Heat-assisted synthesis has been shown to reduce the time necessary to produce high-purity linear peptides, and its application to the synthesis of cyclic peptides may provide similar advantages. To demonstrate the utility of heating in the preparation of a cyclic peptide, the potent melanocortin receptor agonist Melanotan II (MT-II) [1] has been synthesized using the Prelude ${ }^{\circledR}$ X peptide synthesizer. The Prelude ${ }^{\circledR} \mathrm{X}$ is the first instrument to use rapid induction heating, with six parallel and independently heated channels.

Multiple temperature profiles were tested in parallel for the optimization of the cyclization reaction of MT-II, with the lactam formation via the Asp and Lys side chains performed for one or five minutes at both $55^{\circ} \mathrm{C}$ and $85^{\circ} \mathrm{C}$.

$$
\text { Ac-Nle-cyclo[Asp-His-D-Phe-Arg-Trp-Lys]- } \mathrm{NH}_{2}
$$

Fig. 1. Sequence of MT-II peptide.

\section{Results and Discussion}

The synthesis of MT-II peptide using induction heating was found to improve cyclization times and the efficiency of the cyclization reaction. Heating at $55^{\circ} \mathrm{C}$ or $85^{\circ} \mathrm{C}$ was effective for accelerating the reaction, but the highest purity was achieved by heating to $85^{\circ} \mathrm{C}$ for 5 minutes (Table 1, Figure 1).

Induction heating achieved a significant decrease of cyclization time without compromising peptide crude purity. Efficient cyclization was obtained even from one minute cyclization reaction times at two different temperatures.

Table 1. Cyclization times and crude purity for MT-II peptides performed at different temperatures.

\begin{tabular}{ccc}
\hline Temperature $\left({ }^{\circ} \mathrm{C}\right)$ & Cyclization time & Purity $(\%)$ \\
\hline 55 & $1 \mathrm{~min}$ & 68.7 \\
85 & $1 \mathrm{~min}$ & 69.5 \\
55 & $5 \mathrm{~min}$ & 67.8 \\
85 & $5 \mathrm{~min}$ & 72.6 \\
\hline
\end{tabular}


A)

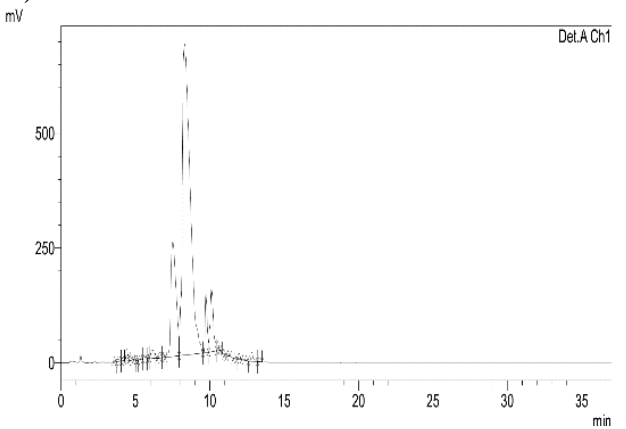

C)

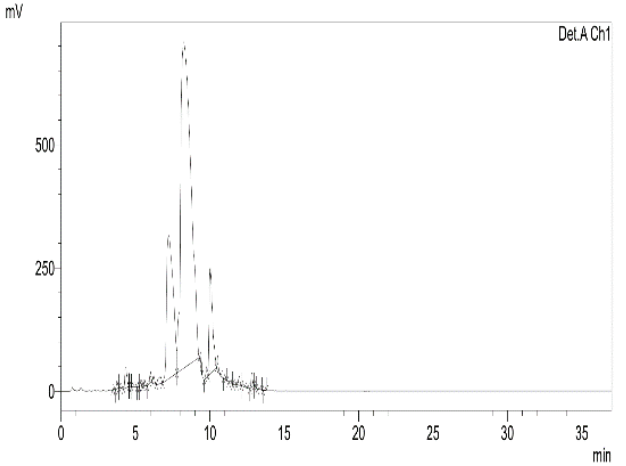

B)

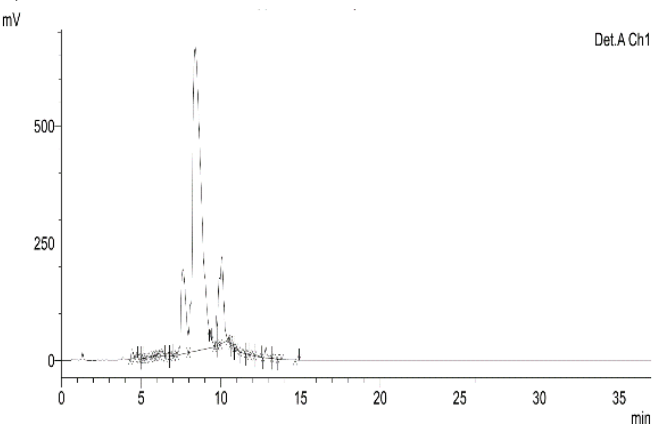

D)

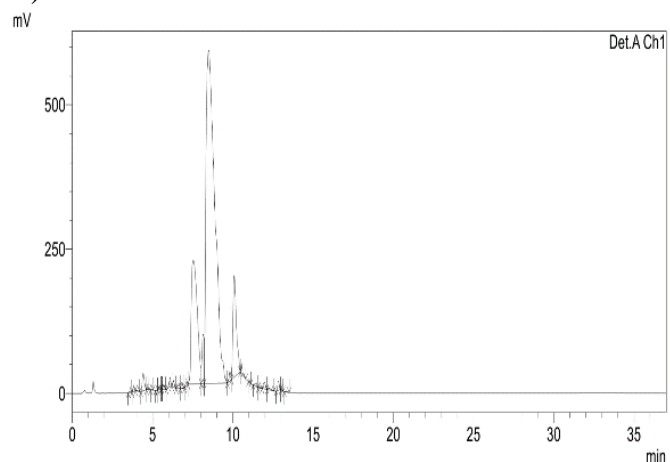

Fig. 2. HPLC analysis of the MT-II cyclic peptide utilizing different protocols. A) 1 min cyclization time at $\left.55^{\circ} \mathrm{C}, \mathrm{B}\right) 1 \mathrm{~min}$ cyclization time at $85^{\circ} \mathrm{C}$, C) 5 min cyclization time at $55^{\circ} \mathrm{C}$, and D) $5 \mathrm{~min}$ cyclization time at $85^{\circ} \mathrm{C}$.

\section{References}

1. Al-Obeidi, F., Hadley, M.E., Pettitt, B.M., Hruby, V.J. J. Am. Chem.Soc. 111, 3413-3416 (1989), http://pubs.acs.org/doi/abs/10.1021/ja00191a044 